\title{
Two enteral solutions with different chloride concentrations administered by naso-ruminal route for fluid therapy in adult cattle
}

\author{
Samuel Rodrigues Alves ${ }^{1^{*}}$ (D) Marcel Ferreira Bastos Avanza ${ }^{1}$ (D) Micheline Ozana da Silva $^{1}$ (D) \\ Pedro Ancelmo Nunes Ermita ${ }^{1}$ (D) Lidiany Lopes Gomes ${ }^{1}$ (D) Lorena Chaves Monteiro ${ }^{1}$ (D) \\ Paulo Vinícius de Morais Santos ${ }^{1}$ (D) Caio Monteiro Costa ${ }^{1}$ (D) Gabriella Maria Morais Ferreira ${ }^{1}$ (D) \\ Felipe Sperandio Mattos $^{1}$ (D) José Dantas Ribeiro Filho ${ }^{1}$
}

'Departamento de Veterinária, Universidade Federal de Viçosa (UFV), 36570-900, Viçosa, MG, Brasil. E-mail: samuelalvesvet@gmail.com. ${ }^{*}$ Corresponding author.

ABSTRACT: Six adult Holstein cows were used in this fluid therapy study. All animals were previously submitted to 24 hours of water and food abstaining period and submitted to both hydration treatments for eight hours in a crossover design 6x2. Two treatments with hypotonic solutions $(190 \mathrm{mOsm} / \mathrm{L})$ with low strong ion difference and different chloride concentrations solutions were executed. Physical, biochemical, blood gas analysis and urinary evaluation were executed in five different experimental times (T-24h, T0h, T4h, T8h e T24h). The hydration period caused plasmatic volume expansion. An increase in faeces humidity, excretion of $\mathrm{Na}^{+}$and $\mathrm{Cl}$ in urine, reduction of PCV, osmolarity, blood and urinary $\mathrm{pH}$ was observed. Both solutions can be used for fluid therapy for adult cattle and solution containing calcium chloride (SECaCl) was the most suitable for use in animals with hypochloraemia.

Key words: biochemical, blood gas analysis, calcium chloride, electrolyte.

Comparação de duas soluções enterais com diferentes concentrações de cloreto administradas por via nasorruminal para hidratação em bovinos adultos

RESUMO: Seis vacas holandesas adultas foram utilizadas neste estudo de hidratação. Todos os animais foram submetidos previamente a 24 horas de jejum hidrico e alimentar e submetidos a ambos os tratamentos de hidratação por oito horas, em delineamento transversal 6x2. Foram realizados dois tratamentos com soluções hipotônicas balanceadas $(190 \mathrm{mOsm} / \mathrm{L})$ com diferentes concentrações de cloretos. Foram realizadas avaliações fisicas, bioquímicas, hemogasometria e avaliação urinária em cinco diferentes tempos experimentais (T-24h, T0h, T4h, T8h e T24h). O periodo de hidratação causou expansão de volume plamático. Foi observado aumento da umidade das fezes e da excreção de $\mathrm{Na}^{+}$e Cl na urina, redução do volume globular, osmolaridade, pH sangüíneo e pH urinário. Ambas as soluções podem ser

usadas para hidratação de bovinos adultos, sendo a solução que contém cloreto de cálcio (SECaCl) a mais indicada para o uso em animais com hipocloremia.

Palavras-chave: analises bioquímicas, cloreto de cálcio, eletrólitos, hemogasometria.

\section{INTRODUCTION}

Metabolic alkalosis is the main acid-base disturbance reported in adult cattle and is caused by prolonged fasting periods and dehydration (ROUSSEL, 2014). In moderately dehydrated animals, metabolic alkalosis occurs because the tubular cells cannot eliminate the excess bicarbonate ions into the lumen (LUKE \& GALLA, 2012).

Irrespective of the cause, fluid therapy should be used for the correction of dehydration and acid-base imbalances (CONSTABLE, 2003a). This therapy re-establishes the cardiac output and improves tissue perfusion. In adult cattle, enteral fluid therapy is an effective route, and is performed by administering solutions using an oro-ruminal or naso-ruminal tube (RIBEIRO FILHO et al., 2011). This route is used often because it is easy to execute, does not require sterile solutions, costs little, and allows deposition of large amounts of solution directly into the rumen. The direct deposition of fluids into the rumen can be used as a reservoir for cattle (CONSTABLE, 2003a; RIBEIRO FILHO et al., 2011).

To prevent the stress caused by successive tube passages, the naso-ruminal route in continuous flow can be used in fluid therapy for long periods, causing minimal discomfort, and allowing animals to eat and drink during the administration of fluid therapy. This route was successfully used in many animals such as cattle (RIBEIRO FILHO et al., 
2011; ERMITA et al., 2018) and horses (AVANZA et al., 2009). In dairy cattle, metabolic alkalosis can cause many undesirable effects, like puerperal hypocalcaemia, which happens often in the transition period (MARTÍN-TERESO \& MARTENS, 2014). Metabolic alkalosis causes a reduction of the osteoclast activity, leading to a low ionic calcium output in the bloodstream (BUSHINSKY, 1996), it also increases the calcium affinity to its binding proteins, reducing ionic calcium bioavailability and thus aggravating hypocalcaemia (KLINE et al., 2005).

The aim of this study was to evaluate the effects of two differently solutions with different chloride concentrations, administered via nasoruminal route in a continuous flow over eight hours in adult dairy cattle, subjected to 24 hours of abstinence from water and food.

\section{MATERIALS AND METHODS}

The study included six adult pasturefed Holstein half-breed dairy cows. All cows were multiparous, not pregnant, in the dry period, with a mean age of five years, with mean weigh of $453.8 \pm 17.3$ $\mathrm{kg}$ and healthy. Cows were housed in large bays with shavings beds and fresh water ad libitum. They were fed with a chopped grass ad libitum (Pennisetum purpureum) and ration (1 kg /animal) twice a day. A cross-over $6 \times 2$ design was adopted for this study. All animals were subjected to both treatments, with a seven-day interval between treatments. Two enteral solutions were proposed as treatments to correct dehydration and cause mild metabolic acidification: a solution with calcium acetate ( $\mathrm{SCaAc}$ ) containing 4 $\mathrm{g}$ of sodium chloride, $1 \mathrm{~g}$ of potassium chloride, $0.5 \mathrm{~g}$ of magnesium chloride, and $2 \mathrm{~g}$ of calcium acetate in $1000 \mathrm{~mL}$ of water (Osmolarity $=190 \mathrm{mOsm} / \mathrm{L})$; while the solution with calcium chloride $\left(\mathrm{SCaCl}_{2}\right)$ contained $4 \mathrm{~g}$ of sodium chloride, $1 \mathrm{~g}$ of potassium chloride, 0.5 $\mathrm{g}$ of magnesium chloride and $2 \mathrm{~g}$ of calcium chloride in $1000 \mathrm{~mL}$ of water (Osmolarity=194 mOsm/L).

The experimental procedure began with a fasting period of 24 hours, with abstinence from both water and food, to promote mild dehydration in the animals $(\mathrm{T}=-24 \mathrm{~h})$. After 24 hours $(\mathrm{T}=0 \mathrm{~h})$, a nasoruminal tube, $2 \mathrm{~m}$ in length and $10 \mathrm{~mm}$ in diameter, connected to a gallon with $20 \mathrm{~L}$ of solution, was introduced. The fluid therapy in continuous flow was set at a speed of $15 \mathrm{~mL} / \mathrm{kg} /$ hour (RIBEIRO FILHO et al., 2011). After eight hours of fluid therapy $(\mathrm{T}=8 \mathrm{~h})$, the treatment was stopped, and the animals were fed and watered ad libitum.

We measured physical parameters and collected samples for laboratory analysis at the following times: $\mathrm{T}=-24 \mathrm{~h}$ (before the fasting period),
$\mathrm{T}=0 \mathrm{~h}$ (start of the fluid therapy), $\mathrm{T}=4 \mathrm{~h}$ (after four hours of treatment), $\mathrm{T}=8 \mathrm{~h}$ (after eight hours of treatment, end of the treatment) and $\mathrm{T}=24 \mathrm{~h}(16$ hours after the end of the treatments, and 24 hours after the beginning of the fluid therapy).

Blood samples were collected from the jugular external vessel, to evaluate biochemical and blood gas analyser profiles, using $21 \mathrm{G}$ needles. The blood was stored in tubes without anti-coagulant, fluoride/EDTA containing tubes were used for plasma obtainment, and lithium heparin syringes were used for collecting samples for blood gas analysis. Manual technique packed cell volume (PCV), osmolarity (OSM), sodium $\left(\mathrm{Na}^{+}\right)$, chloride $\left(\mathrm{Cl}^{-}\right)$, potassium $\left(\mathrm{K}^{+}\right)$, total calcium $\left(\mathrm{tCa}^{2+}\right)$, magnesium $\left(\mathrm{Mg}^{2+}\right)$, glucose (GLU), lactate (LAC), urea (URE), creatinine (CRE), $\mathrm{pH}$, carbon dioxide pressure $\left(\mathrm{pCO}_{2}\right)$, bicarbonate $\left(\mathrm{HCO}_{3}{ }^{-}\right)$, and base excess $(\mathrm{BE})$ were measured. Urine was collected by perineal massage, measuring the urinary volume (UV), in $\mathrm{T}=4 \mathrm{~h}$ and $\mathrm{T}=8 \mathrm{~h}$, and samples were collected in all times to evaluate urinary $\mathrm{pH}\left(\mathrm{pH}_{\mathrm{Ur}}\right)$, specific gravity $(\mathrm{SG})$ on refractometer, urinary sodium $\left(\mathrm{Na}_{\mathrm{Ur}}\right)$, potassium $\left(\mathrm{K}_{\mathrm{Ur}}\right)$, and chloride $\left(\mathrm{Cl}_{\mathrm{Ur}}\right)$. Faeces were collected directly from the rectal ampulla, weighed and dehydrated in a kiln to calculate the humidity percentage (FHP).

The biochemical urinary and serum analyses were performed using an automatic biochemistry analyser (HumaStar300 - ${ }^{\circ} 2017$ InVitro Diagnóstica), a flame spectrophotometer for $\mathrm{Na}^{+}$and $\mathrm{K}^{+}$(BFC-300 - Benfer ${ }^{\odot}$ ) and an osmometer (Model $3320^{\circ}$ - Advanced Instruments). The blood gas analysis were evaluated using an OMNI C $\left({ }^{\circ} 2018\right.$ Roche Diagnóstica Brasil Ltda) hemogasometer and the urinary $\mathrm{pH}$ was evaluated using a portable pHmeter (Kasvi ${ }^{\odot}$, model K39-0014P).

Descriptive statistical analysis was performed on all data. Normality was evaluated by Shapiro-Wilk's test. Sphericity was evaluated by Mauchly's test. When normality and sphericity were confirmed, factorial repeated measures ANOVA was used. Tukey's post-hoc test was used when statistical significance was reported in the ANOVA test. All analyses were performed with SPSS Statistics 20 (IBM - SPSS, Chicago), and P-values less than 0.05 were considered significant.

\section{RESULTS}

Results for physical parameters and biochemical profiles, for electrolyte values, hemogasometry parameters and urinary data are shown in table 1 , table 2 and table 3. 


\section{DISCUSSION}

None of the animals showed any sign of stress due to the fluid therapy technique, and no alterations were observed in the basic physical parameters (RADOSTITS et al., 2007).This confirmed that this technique is less stressful than parenteral fluid therapy, allowing the animals to behave normally during the procedure (RIBEIRO FILHO et al., 2011).

The FHP (Table 1) is a good indicator of the hydration of the gastrointestinal tract. With the deprivation of water for 24 hours, the animals used of the water inside the rumen and intestines, showing the importance of these compartments to the homeostasis of ruminants (CONSTABLE, 2003a). With the enteral fluid therapy by continuous flow for eight hours, the FHP increased, showing the effectiveness of the therapy in increasing the humidity inside the intestinal compartment. The highest FHP values occurred at $\mathrm{T}=24 \mathrm{~h}$, demonstrating the role of the rumen as a reservoir providing water to the animals for long periods. In this study, the PCV values (Table 1) directly showed the effects of the therapy on the blood stream (RIBEIRO FILHO et al., 2011). The speed of $15 \mathrm{~mL} / \mathrm{kg} / \mathrm{h}$ in continuous flow for eight hours $(\mathrm{T}=8 \mathrm{~h})$ via the enteral route was able to cause volemic expansion in adult dairy cattle. OSM alterations are shown in table 1 . The fasting period was enough to increase the values at $\mathrm{T}=0 \mathrm{~h}$. Initial values were only recovered at $\mathrm{T}=24 \mathrm{~h}$. Considering how OSM modulates water reabsorption (HALL, 2011), the results showed stability and control of this component by these animals, who use it as a tool to regulate water losses and absorption. Again, the rumen acts as a reservoir of water, maintaining hydration for long times and avoiding fast volume expansions of bloodstream, thus allowing the organism to slowly adapt to change.

GLU and LAC levels are shown in table 1. The GLU levels did not vary, even though no glucose precursors were added to the solutions. This finding is explained by the use of other routes of glycogenesis, such as fatty acid, glycerol, and amino acid metabolic pathways for glucose production (KOZLOSKI, 2011). $\mathrm{LAC}$ levels were low in the $\mathrm{SCaCl} 2$ group, but still within the limits for healthy bovines (KANEKO et al., 2008). Levels of CRE and URE, good markers of hydration and kidney function (KANEKO et al, 2008), are shown in table 1 . The dehydration period $(\mathrm{T}=$ -24h) was not intense enough to cause an increase in

Table 1 - Physical and biochemical parameters of cows submitted to treatment with acidifying solutions: Faeces humidity (FHP - \% of water), packed cell volume (PCV - \%), osmolarity (OSM - mOsm/L), glucose (GLU - mg/dL), lactate (LAC - mg/dL), creatinine $(\mathrm{CRE}-\mathrm{mg} / \mathrm{dL})$, urea $(\mathrm{URE}-\mathrm{mg} / \mathrm{dL})$, specific gravity $(\mathrm{SG}-\mathrm{g} / \mathrm{dL})$ and urinary volume $(\mathrm{UV}-\mathrm{L})$.

\begin{tabular}{|c|c|c|c|c|c|c|}
\hline & Treatment & $\mathrm{T}=-24 \mathrm{~h}$ & $\mathrm{~T}=0 \mathrm{~h}$ & $\mathrm{~T}=4 \mathrm{~h}$ & $\mathrm{~T}=8 \mathrm{~h}$ & $\mathrm{~T}=24 \mathrm{~h}$ \\
\hline \multirow{2}{*}{ FHP } & $\mathrm{SCaAc}$ & $85.0 \pm 1.6^{\mathrm{a}}$ & $80.8 \pm 1.1^{b}$ & $82.8 \pm 1.9^{\mathrm{ab}}$ & $84.1 \pm 1.7^{\mathrm{a}}$ & $86.2 \pm 3.2^{\mathrm{a}}$ \\
\hline & $\mathrm{SCaCl}_{2}$ & $83.9 \pm 1.4^{\mathrm{ab}}$ & $81.1 \pm 2.7^{\mathrm{bc}}$ & $82.2 \pm 0.9^{c}$ & $83.1 \pm 1.4^{\mathrm{bc}}$ & $85.6 \pm 1.2^{\mathrm{a}}$ \\
\hline \multirow{2}{*}{$\mathrm{PCV}$} & $\mathrm{SCaAc}$ & $28.2 \pm 5.0^{\mathrm{a}}$ & $28.0 \pm 4.1^{\mathrm{a}}$ & $27.1 \pm 2.3^{\mathrm{ab}}$ & $25.1 \pm 3.9^{\mathrm{b}}$ & $27.0 \pm 4.1^{\mathrm{ab}}$ \\
\hline & $\mathrm{SCaCl}_{2}$ & $27.5 \pm 2.7^{\mathrm{a}}$ & $28.8 \pm 4.2^{\mathrm{a}}$ & $27.1 \pm 2.4^{\mathrm{a}}$ & $25.6 \pm 3.3^{\mathrm{b}}$ & $27.5 \pm 2.4^{\mathrm{ab}}$ \\
\hline \multirow{2}{*}{ OSM } & $\mathrm{SCaAc}$ & $280.3 \pm 5.2^{\mathrm{b}}$ & $290.2 \pm 5.3^{\mathrm{a}}$ & $289.5 \pm 5.1^{\mathrm{a}}$ & $288.3 \pm 2.9^{\mathrm{a}}$ & $282.8 \pm 3.1^{\mathrm{b}}$ \\
\hline & $\mathrm{SCaCl}_{2}$ & $283.0 \pm 4.9^{\mathrm{b}}$ & $288.0 \pm 5.7^{\mathrm{ab}}$ & $289.7 \pm 5.6^{\mathrm{a}}$ & $291.0 \pm 2.4^{\mathrm{a}}$ & $284.0 \pm 3.2^{\mathrm{b}}$ \\
\hline \multirow{2}{*}{ GLU } & $\mathrm{SCaAc}$ & $67.2 \pm 8.0$ & $67.9 \pm 11.9$ & $66.3 \pm 9.1$ & $62.9 \pm 10.8$ & $73.8 \pm 4.5$ \\
\hline & $\mathrm{SCaCl}_{2}$ & $68.3 \pm 2.1$ & $68.0 \pm 9.1$ & $65.5 \pm 9.2$ & $66.2 \pm 7.0$ & $72.6 \pm 3.7$ \\
\hline \multirow{2}{*}{ LAC } & $\mathrm{SCaAc}$ & $7.2 \pm 1.5^{\mathrm{A}}$ & $6.5 \pm 1.4^{\mathrm{A}}$ & $5.5 \pm 1.4^{\mathrm{A}}$ & $7.3 \pm 2.1^{\mathrm{A}}$ & $6.2 \pm 0.4^{\mathrm{A}}$ \\
\hline & $\mathrm{SCaCl}_{2}$ & $6.7 \pm 1.0^{\mathrm{A}}$ & $6.5 \pm 3.3^{\mathrm{A}}$ & $7.0 \pm 2.8^{\mathrm{A}}$ & $6.2 \pm 2.3^{B}$ & $5.3 \pm 0.5^{\mathrm{B}}$ \\
\hline \multirow{2}{*}{ CRE } & $\mathrm{SCaAc}$ & $0.9 \pm 0.2$ & $1.0 \pm 0.2$ & $1.0 \pm 0.2$ & $1.0 \pm 0.3$ & $0.9 \pm 0.2$ \\
\hline & $\mathrm{SCaCl}_{2}$ & $1.0 \pm 0.2$ & $1.1 \pm 0.3$ & $1.0 \pm 0.3$ & $1.1 \pm 0.2$ & $0.9 \pm 0.4$ \\
\hline \multirow{2}{*}{ URE } & $\mathrm{SCaAc}$ & $26.9 \pm 10.6^{\mathrm{b}}$ & $38.4 \pm 13.5^{\mathrm{a}}$ & $37.5 \pm 10.0^{\mathrm{a}}$ & $36.2 \pm 7.9^{\mathrm{a}}$ & $22.3 \pm 9.6^{b}$ \\
\hline & $\mathrm{SCaCl}_{2}$ & $24.5 \pm 10.0^{\mathrm{b}}$ & $41.2 \pm 10.3^{\mathrm{a}}$ & $36.8 \pm 13.5^{\mathrm{ac}}$ & $36.6 \pm 9.6^{\mathrm{a}}$ & $20.2 \pm 9.6^{b}$ \\
\hline \multirow{2}{*}{ SG } & $\mathrm{SCaAc}$ & $1040.0 \pm 11.3$ & $1042.0 \pm 2.8$ & $1032.0 \pm 14.8$ & $1006.0 \pm 2.8$ & $1030.0 \pm 5.7$ \\
\hline & $\mathrm{SCaCl} 2$ & $1036.0 \pm 7.7^{\mathrm{ab}}$ & $1045.0 \pm 7.1^{\mathrm{ab}}$ & $1039.0 \pm 1.4^{\mathrm{a}}$ & $1006.5 \pm 1.4^{b}$ & $1025.0 \pm 1.4^{\mathrm{a}}$ \\
\hline \multirow[b]{2}{*}{ UV } & SCaAc & - & - & $1.4 \pm 0.5^{\mathrm{b}}$ & $5,3 \pm 3,5^{\mathrm{a}}$ & - \\
\hline & $\mathrm{SCaCl}_{2}$ & - & - & $1.8 \pm 1.2^{\mathrm{b}}$ & $6,8 \pm 5,1^{\mathrm{a}}$ & - \\
\hline
\end{tabular}

Means followed by different lowercase letters on the same line and different capitals in the same column differ from each other $(\mathrm{P} \leq 0.05)$. 
Table 2 - Blood end urinary electrolytes of cows submitted to treatment with acidifying solutions: Sodium (Na $\left.{ }^{+}-\mathrm{mEq}^{\mathrm{L}} \mathrm{L}\right)$, potassium $\left(\mathrm{K}^{+}\right.$ $-\mathrm{mEq} / \mathrm{L})$, chloride $\left(\mathrm{Cl}^{-}-\mathrm{mEq} / \mathrm{L}\right)$, total calcium $\left(\mathrm{tCa}^{2+}-\mathrm{mg} / \mathrm{dL}\right)$, magnesium $\left(\mathrm{Mg}^{2+}-\mathrm{mg} / \mathrm{dL}\right)$, urinary sodium $(\mathrm{Na} \mathrm{Ur}-\mathrm{mEq} / \mathrm{L})$, urinary potassium $\left(\mathrm{K}_{\mathrm{Ur}}-\mathrm{mEq} / \mathrm{L}\right)$ and urinary chloride $\left(\mathrm{Cl}_{\mathrm{Ur}}-\mathrm{mEq} / \mathrm{L}\right)$.

\begin{tabular}{|c|c|c|c|c|c|c|}
\hline & Treatment & $\mathrm{T}=-24 \mathrm{~h}$ & $\mathrm{~T}=0 \mathrm{~h}$ & $\mathrm{~T}=4 \mathrm{~h}$ & $\mathrm{~T}=8 \mathrm{~h}$ & $\mathrm{~T}=24 \mathrm{~h}$ \\
\hline \multirow{2}{*}{$\mathrm{Na}^{+}$} & $\mathrm{SCaAc}$ & $139.0 \pm 1.4$ & $141.0 \pm 2.8$ & $139.0 \pm 1.4$ & $143.5 \pm 0.7$ & $141.5 \pm 2.1$ \\
\hline & $\mathrm{SCaCl}^{2}$ & $138.5 \pm 2.1$ & $140.0 \pm 5.7$ & $142.0 \pm 2.8$ & $139.0 \pm 1.4$ & $134.5 \pm 2.1$ \\
\hline \multirow{2}{*}{$\mathrm{K}^{+}$} & $\mathrm{SCaAc}$ & $4.4 \pm 0.4$ & $4.7 \pm 0.6$ & $4.1 \pm 0.5$ & $4.2 \pm 0.3$ & $4.5 \pm 0.6$ \\
\hline & $\mathrm{SCaCl}^{2}$ & $4.1 \pm 0.4$ & $4.4 \pm 0.3$ & $4.4 \pm 0.6$ & $4.3 \pm 0.3$ & $4.3 \pm 0.5$ \\
\hline \multirow{2}{*}{$\mathrm{Cl}^{-}$} & $\mathrm{SCaAc}$ & $93.2 \pm 0.7$ & $88.8 \pm 4.5$ & $86.4 \pm 6.4$ & $90.6 \pm 2.0$ & $93.2 \pm 2.5$ \\
\hline & $\mathrm{SCaCl}^{2}$ & $95.0 \pm 1.8$ & $95.2 \pm 1.7$ & $95.0 \pm 0.5$ & $94.0 \pm 1.2$ & $97.4 \pm 0.5$ \\
\hline \multirow{2}{*}{$\mathrm{tCa}^{2+}$} & $\mathrm{SCaAc}$ & $8.5 \pm 1.0$ & $8.7 \pm 1.4$ & $8.0 \pm 0.6$ & $8.2 \pm 0.8$ & $8.5 \pm 1.4$ \\
\hline & $\mathrm{SCaCl}^{2}$ & $8.8 \pm 0.4$ & $8.3 \pm 1.6$ & $8.0 \pm 1.3$ & $8.7 \pm 0.8$ & $8.0 \pm 1.3$ \\
\hline \multirow{2}{*}{$\mathrm{Mg}^{2+}$} & $\mathrm{SCaAc}$ & $2.6 \pm 0.3^{\mathrm{a}}$ & $2.3 \pm 0.5^{\mathrm{ab}}$ & $1.8 \pm 0.6^{\mathrm{b}}$ & $2.1 \pm 0.3^{b}$ & $2.1 \pm 0.1^{\mathrm{b}}$ \\
\hline & $\mathrm{SCaCl}^{2}$ & $2.6 \pm 0.1^{\mathrm{a}}$ & $2.3 \pm 0.2^{\mathrm{b}}$ & $2.2 \pm 0.6^{\mathrm{ab}}$ & $2.1 \pm 0.2^{\mathrm{b}}$ & $2.5 \pm 0.6^{\mathrm{ab}}$ \\
\hline \multirow{2}{*}{$\mathrm{Na}_{\mathrm{Ur}}$} & $\mathrm{SCaAc}$ & $5.0 \pm 4.6^{\mathrm{b}}$ & $20.7 \pm 23.7^{b}$ & $38.7 \pm 35.2^{\mathrm{ab}}$ & $86.7 \pm 49.3^{\mathrm{ab}}$ & $93.3 \pm 9.3^{\mathrm{a}}$ \\
\hline & $\mathrm{SCaCl}^{2}$ & $20.0 \pm 10.0^{\mathrm{b}}$ & $23.3 \pm 11.5^{\mathrm{b}}$ & $16.7 \pm 11.5^{\mathrm{b}}$ & $46.7 \pm 35.1^{\mathrm{b}}$ & $176.7 \pm 25.2^{\mathrm{a}}$ \\
\hline \multirow{2}{*}{$\mathrm{K}_{\mathrm{Ur}}$} & $\mathrm{SCaAc}$ & $245.1 \pm 92.4^{\mathrm{a}}$ & $148.3 \pm 34.3^{\mathrm{a}}$ & $61.8 \pm 60.5^{\mathrm{bc}}$ & $29.4 \pm 4.4^{\mathrm{c}}$ & $187.5 \pm 69^{\mathrm{ab}}$ \\
\hline & $\mathrm{SCaCl}^{2}$ & $303.0 \pm 19.1^{\mathrm{a}}$ & $207.8 \pm 22.0^{\mathrm{b}}$ & $144.8 \pm 88^{\text {bcd }}$ & $49.0 \pm 21.8^{d}$ & $150.0 \pm 30.0^{\mathrm{c}}$ \\
\hline \multirow[b]{2}{*}{$\mathrm{Cl}_{\mathrm{Ur}}$} & $\mathrm{SCaAc}$ & $37.8 \pm 20.6^{\mathrm{ab}}$ & $30.0 \pm 21.0^{\mathrm{ab}}$ & $12.1 \pm 7.6^{\mathrm{b}}$ & $22.9 \pm 16.3^{\mathrm{ab}}$ & $89.8 \pm 12.7^{\mathrm{a}}$ \\
\hline & $\mathrm{SCaCl}^{2}$ & $44.1 \pm 28.5^{\mathrm{ab}}$ & $30.7 \pm 15.9^{b}$ & $13.1 \pm 6.7^{b}$ & $14.8 \pm 2.4^{\mathrm{b}}$ & $87.4 \pm 8.7^{\mathrm{a}}$ \\
\hline
\end{tabular}

Means followed by different lowercase letters on the same line and different capitals in the same column differ from each other $(\mathrm{P} \leq 0.05)$.

CRE levels. The URE levels better show the effects of the fasting period $(\mathrm{T}=0 \mathrm{~h})$ and the post-hydration period $(\mathrm{T}=24 \mathrm{~h})$. The URE levels were increased by the decrease of kidney activity at $\mathrm{T}=0 \mathrm{~h}$, but the enteral fluid therapy was able to restore such activity (ERMITA et al., 2018). The use of amino acids for glycogenesis helps to increase the concentration of nitrogen derivatives in the blood stream (KOZLOSLI, 2011). The SG (Table 1) is a good marker of hydration status and kidney activity. In both groups, a decrease in SG was observed at $\mathrm{T}=8 \mathrm{~h}$ with an increase in the $\mathrm{UV}$ in $\mathrm{T}=8 \mathrm{~h}$ (Table 1 ). This variables showed effects of the solution in the organism, mainly improvement of kidney function due to increase of the total blood

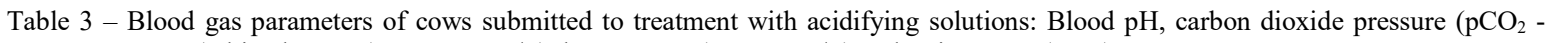
$\mathrm{mmHg})$, bicarbonate $\left(\mathrm{HCO}_{3}-\mathrm{mEq} / \mathrm{L}\right)$, base excess $(\mathrm{BE}-\mathrm{mEq} / \mathrm{L})$ and urinary $\mathrm{pH}\left(\mathrm{pH}_{\mathrm{Ur}}\right)$.

\begin{tabular}{|c|c|c|c|c|c|c|}
\hline & Treatment & $\mathrm{T}=-24 \mathrm{~h}$ & $\mathrm{~T}=0 \mathrm{~h}$ & $\mathrm{~T}=4 \mathrm{~h}$ & $\mathrm{~T}=8 \mathrm{~h}$ & $\mathrm{~T}=24 \mathrm{~h}$ \\
\hline \multirow{2}{*}{$\mathrm{pH}$} & SCaAc & $7.42 \pm 0.03^{\mathrm{ab}}$ & $7.41 \pm 0.02^{\mathrm{bc}}$ & $7.42 \pm 0.02^{\mathrm{bc}}$ & $7.45 \pm 0.03^{\mathrm{a}}$ & $7.40 \pm 0.04^{\mathrm{c}}$ \\
\hline & $\mathrm{SCaCl}_{2}$ & $7.43 \pm 0.03^{\mathrm{ab}}$ & $7.40 \pm 0.02^{\mathrm{bc}}$ & $7.40 \pm 0.02^{\mathrm{bc}}$ & $7.44 \pm 0.01^{\mathrm{a}}$ & $7.38 \pm 0.02^{c}$ \\
\hline \multirow{2}{*}{$\mathrm{pCO}_{2}$} & $\mathrm{SCaAc}$ & $43.5 \pm 2.0^{\mathrm{b}}$ & $46.0 \pm 3.6^{\mathrm{ab}}$ & $46.7 \pm 2.6^{\mathrm{a}}$ & $43.3 \pm 2.7^{\mathrm{bc}}$ & $42.0 \pm 1.9^{c}$ \\
\hline & $\mathrm{SCaCl}_{2}$ & $43.8 \pm 3.6^{\mathrm{ab}}$ & $45.3 \pm 5.7^{\mathrm{ab}}$ & $45.7 \pm 3.7^{\mathrm{a}}$ & $43.5 \pm 4.7^{\mathrm{ab}}$ & $39.7 \pm 1.9^{\mathrm{b}}$ \\
\hline \multirow{2}{*}{$\mathrm{HCO}_{3}$} & $\mathrm{SCaAc}$ & $28.2 \pm 1.4^{\mathrm{Aa}}$ & $28.9 \pm 2.3^{\mathrm{Aa}}$ & $29.5 \pm 1.9^{\mathrm{Aa}}$ & $29.3 \pm 2.2^{\mathrm{Aa}}$ & $25.3 \pm 1.8^{\mathrm{Ab}}$ \\
\hline & $\mathrm{SCaCl}_{2}$ & $28.2 \pm 1.9^{\mathrm{Aa}}$ & $27.5 \pm 3.5^{\mathrm{Aa}}$ & $27.9 \pm 2.2^{\mathrm{Aa}}$ & $28.9 \pm 2.4^{\mathrm{Aa}}$ & $23.0 \pm 1.4^{\mathrm{Bb}}$ \\
\hline \multirow{2}{*}{$\mathrm{BE}$} & $\mathrm{SCaAc}$ & $3.3 \pm 1.7^{\mathrm{a}}$ & $3.6 \pm 2.1^{\mathrm{a}}$ & $4.1 \pm 1.8^{\mathrm{a}}$ & $4.7 \pm 2.4^{\mathrm{a}}$ & $0.3 \pm 2.1^{\mathrm{b}}$ \\
\hline & $\mathrm{SCaCl}_{2}$ & $3.3 \pm 1.8^{\mathrm{a}}$ & $2.1 \pm 2.9^{\mathrm{a}}$ & $2.6 \pm 1.9^{\mathrm{a}}$ & $4.2 \pm 1.7^{\mathrm{a}}$ & $-1.9 \pm 1.6^{b}$ \\
\hline \multirow{2}{*}{$\mathrm{pH}_{\mathrm{Ur}}$} & $\mathrm{SCaAc}$ & $7.90 \pm 0.35$ & $7.43 \pm 0.67$ & $7.55 \pm 0.2$ & $7.75 \pm 0.15$ & $6.23 \pm 1.12$ \\
\hline & $\mathrm{SCaCl}_{2}$ & $8.14 \pm 0.04^{\mathrm{a}}$ & $8.19 \pm 0.09^{\mathrm{a}}$ & $8.15 \pm 0.02^{\mathrm{a}}$ & $7.75 \pm 0.53^{\mathrm{a}}$ & $5.31 \pm 0.18^{b}$ \\
\hline
\end{tabular}

Means followed by different lowercase letters on the same line and different capitals in the same column differ from each other ( $\mathrm{P} \leq 0.05$ ). 
volume in eight hours of fluid therapy without any kidney overload (ERMITA et al., 2018).

The $\mathrm{Na}^{+}, \mathrm{K}^{+}, \mathrm{Cl}^{-}$and $\mathrm{tCa}^{2+}$ values are shown in table 2. Electrolytes can directly influence the acid-base balance. The lack of variation in blood concentration for these electrolytes shows that concentration of these electrolyte in the solutions are well adapted for maintaining electrolyte homeostasis in adult dairy cattle. Another important concern was whether the $\mathrm{tCa}^{2+}$ amount in both solutions was enough to keep $\mathrm{tCa}^{2+}$ within limits during the whole treatment period (KANEKO et al, 2008). The $\mathrm{Mg}^{2+}$ levels are presented in table 2. Serum $\mathrm{Mg}^{2+}$ did not have specific mechanisms of control as other electrolytes, and this allowed diverse physiological mechanisms to affect its serum concentration (MARTÍN-TERESO \& MARTENS, 2014). Notwithstanding the decrease in $\mathrm{Mg}^{2+}$ concentration, this electrolyte remained within normal values for adult cattle (KANEKO et al., 2008).

The mean $\mathrm{Na}_{\mathrm{Ur}}$ levels are also shown in table 2. With the blood volume increasing during the fluid therapy period, the antidiuretic hormone level decreases and; consequently, so does the action of the renin-angiotensin-aldosterone system, allowing the kidneys to excrete more $\mathrm{Na}_{\mathrm{Ur}}$ and water (HALL, 2011). In this study, in the hydration period, $\mathrm{Na}_{\mathrm{Ur}}$ increased to reach its highest values at $\mathrm{T}=24 \mathrm{~h}$ for both solutions, but serum $\mathrm{Na}^{+}$was not altered, showing that the solutions, even if hypotonic, are balanced, and can be used for long periods. The values of $\mathrm{K}_{\mathrm{Ur}}$ are presented in table 2. At $\mathrm{T}=0 \mathrm{~h}$, the high concentration of $\mathrm{K}_{\mathrm{Ur}}$ was caused by the forced trade with $\mathrm{Na}_{\mathrm{Ur}}$, under the action of the aldosterone hormone which protects the organism from dehydration (HALL, 2011). During the hydration therapy, the $\mathrm{K}_{\mathrm{Ur}}$ decreases because of decreased aldosterone effects. The aldosterone hormone is the main modulator of $\mathrm{K}_{\mathrm{Ur}}$ excretion, and acts by increasing the effects of the $\mathrm{Na} / \mathrm{K}$-ATPase in the basolateral membrane of the collecting ducts and, thus, increasing $\mathrm{Na}^{+}$absorption and $\mathrm{K}^{+}$excretion (ERMITA et al., 2018). The $\mathrm{Cl}_{\mathrm{Ur}}$ levels are displayed in table 2. In an effort to maintain electroneutrality, high amounts of ClUr were excreted together with $\mathrm{Na}_{\mathrm{Ur}}$ at $\mathrm{T}=24 \mathrm{~h}$ (HALL, 2011). During the fasting period, as $\mathrm{Na}_{\mathrm{Ur}}$ decreases, $\mathrm{Cl}_{\mathrm{Ur}}$ decreases too, and after the hydration period, an increase in the elimination of both electrolytes was noted. The $\mathrm{Cl}^{-}$excess in the solutions can increase the excretion of $\mathrm{Cl}_{\mathrm{Ur}}$ at $\mathrm{T}=24 \mathrm{~h}$.

Variations of blood $\mathrm{pH}$ (Table 3) are certainly important. In this study, the $\mathrm{pH}$ decreased significantly at $\mathrm{T}=24 \mathrm{~h}$. This decrease in blood $\mathrm{pH}$ in $\mathrm{T}=24 \mathrm{~h}$ can be caused by the late absorption of the solutions with low SID and the food ingestion after $\mathrm{T}=8 \mathrm{~h}$. Even with the $\mathrm{pH}$ decreases, it remains within normal bovine limits (Smith, 2015). Another component of the blood gas analysis evaluation is the respiratory component $\mathrm{pCO}_{2}$ (Table 3 ). The values of $\mathrm{pCO}_{2}$ decreased significantly in the post-hydration period $(\mathrm{T}=24 \mathrm{~h})$. To compensate for alterations caused by the administration of the solutions, the organism increases its output of $\mathrm{CO}_{2}$ through respiration to control the body $\mathrm{pH}$ (KANEKO et al, 2008).

The $\mathrm{HCO}_{3}$ (Table 3) is an important base and negative charge in the bloodstream, and upon administration of solutions with low $\mathrm{SID}, \mathrm{HCO}_{3}$ can be eliminated for compensation (CONSTABLE, 2003b). In this study, there was a significant decrease in $\mathrm{HCO}_{3}$ at $\mathrm{T}=24 \mathrm{~h}$ in both groups, that is at the same time when a high amount of fluid with low SID had been absorbed and the lowest $\mathrm{pH}$ values were measured. The $\mathrm{SCaCl}_{2}$ caused the most important decrease in the $\mathrm{HCO}_{3}$ values due to the higher amount of chloride in the solution. The lowest BE (Table 3) was measured at $\mathrm{T}=24 \mathrm{~h}$, confirming that the low SID solutions administered had been mostly absorbed. The normal state for a ruminant is a slightly alkaline state $(\mathrm{BE}=0-6 \mathrm{mEq} / \mathrm{L}$ - CONSTABLE, 2003a) and, even with the absence of a significant difference between the two solutions, the $\mathrm{SCaCl}_{2}$ solution caused more acidification when compared to the SCaAc. The pHUr values are shown in Table 3. One of the main functions of the kidneys is to maintain organism homeostasis (RADOSTITS et al., 2007). Upon administration of acidifying solutions, at $\mathrm{T}=24 \mathrm{~h}$, with the excess of protons in the organism, kidneys try to wash them out, resulting in a low $\mathrm{pH}_{\mathrm{Ur}}$. The $\mathrm{pH}_{\mathrm{Ur}}$ is often used to monitor the acid-base state of the organism in dairy farms using anionic diets (MARTÍN-TERESO \& MARTENS, 2014).

Improving the number of animals and bovines with marked metabolic alkalosis will help to understand better all effects of these low SID solutions. Results of this study showed good response of the dairy cattle to the infused solutions at speed of $15 \mathrm{~mL} / \mathrm{Kg} /$ hour in continuous flow by naso-ruminal route. Therefore, new projects with fluid therapy for longer periods, in this administration speed, can exacerbate response of bovines to low SID solutions.

\section{CONCLUSION}

Both solutions can be used for fluid therapy in adult cattle. The $\mathrm{SCaCl}_{2}$ represents the better treatment option to bovines with hypochloraemia due the higher relative chloride concentration. New 
clinical trials, with cattle presenting dehydration and alkalosis, can show the real effects and viability of these acidifying solutions in the buiatric routine.

\section{ACKNOWLEDGEMENTS}

We are thankful, to Fundação de Amparo à Pesquisa do Estado de Minas Gerais (FAPEMIG) and was financed in part by the Coordenação de Aperfeiçoamento de Pessoal de Nível Superior (CAPES), Brasil.

\section{BIOETHICS AND BIOSSECURITY COMMITTEE APPROVAL}

The study was approved by the Ethical Commission on the Use of Animals (CEUA / UFV) under protocol number $34 / 2018$.

\section{DECLARATION OF CONFLICT OF INTERESTS}

The authors declare no conflict of interest. The founding sponsors had no role in the design of the study; in the collection, analyses, or interpretation of data; in the writing of the manuscript, and in the decision to publish the results.

\section{AUTHORS' CONTRIBUTIONS}

The authors contributed equally to the manuscript.

\section{REFERENCES}

AVANZA, M.F.B. et al. Enteral fluid therapy in horses electrolyte solution associated or not with glucose, maltodextrine and magnesium sulphate: laboratory results. Ciência Rural, v.39, p.1126-1133, 2009. Available from: <http://www.scielo. br/scielo.php?pid $=$ S0103-84782009000400024\&script $=$ sci arttext\&tlng=pt $>$. Accessed: Jul. 2018. doi: 10.1590/S010384782009005000021

BUSHINSKY, D.A. Metabolic alkalosis decreases bone calcium efflux by suppressing osteoclasts and stimulating osteoblasts. American Journal of Physiology-Renal Physiology, v.271, p.216-222, 1996. Available from: < https://www.physiology.org/ doi/abs/10.1152/ajprenal.1996.271.1.F216>. Accessed Jul. 22, 2018. doi: 10.1152/ajprenal.1996.271.1.F216.

CARLSON, G.P.; BRUSS, M. Fluid, electrolyte and acid-base balance. In: KANEKO, J. Clinical biochemistry of domestic animals, 6 ed. London: Academic Press, 2008. p.529-559.

CONSTABLE, P.D. Fluid and electrolyte therapy in ruminants. Veterinary Clinics of North America: Food Animal Practice, v.19, p.557-597, 2003(a). Available from: <https://www.vetfood. theclinics.com/article/S0749-0720(03)00054-9/abstract $>$. Accessed Jul. 22, 2018. doi:10.1016/S0749-0720(03)00054-9.

CONSTABLE, P.D. Hyperchloremic acidosis: the classic example of strong ion acidosis. Anesthesia and Analgesia, v.96, p.919-
922, 2003(b). Available from: <https://ovidsp.dc2.ovid.com/ sp3.33.0b/ovidweb.cgi? WebLinkFrameset=1\&S=OBKOFPPCI BEBPODCJPCKEHBFOHBAAA00>. Accessed Jul. 22, 2018. doi:10.1213/01.ANE.0000053256.77500.9D.

ERMITA, P.A.N. et al. Enteral fluid therapy administered in continuous flow by naso-ruminal route using three maintenance electrolyte solutions: effects on physiological biomarkers and the hemogram of bovines. Ciência Rural, v.48, e20180217, 2018. Available from: <http://www.scielo.br/scielo.php?pid=S0103$84782018000800603 \&$ script $=$ sci arttext $>$. Accessed Jul. 22, 2018. doi:10.1590/0103-8478cr20180217.

HALL, J.E. Guyton and Hall textbook of medical physiology. 12 ed. St. Louis: Elsevier Saunders, 2011.pp. 1120.

KANEKO, J.J. et al. Clinical biochemistry of domestics animals. 6 ed. San Diego: Academics Press, 2008, pp. 928.

KLINE, K. et al. Effects of intravenous sodium bicarbonate and sodium acetate on equine acid-base status. Journal of Equine Veterinary Science, v.25, p.349-354 2005. Available from: $\quad<$ https://www.sciencedirect.com/science/article/pii/ S0737080605002765>. Accessed Jul. 22, 2018. doi:10.1016/j. jevs.2005.07.003.

KOZLOSKI, G.V. Bioquímica dos ruminantes. $3^{\mathrm{a}}$ ed., Fundação de Apoio a Tecnologia e Ciencia-Editora UFSM, 2011, pp. 212.

LUKE, R.G.; GALLA, J.'H. It is chloride depletion alkalosis, not contraction alkalosis. Journal of the American Society of Nephrology, v.23, n.2, p.204-207, 2012. Available from: <https:// jasn.asnjournals.org/content/23/2/204.short>. Accessed Jul. 22, 2018. doi:10.1681/ASN.2011070720.

MARTÍN-TERESO, J.; MARTENS, H. Calcium and magnesium physiology and nutrition in relation to the prevention of milk fever and tetany (dietary management of macrominerals in preventing disease). Veterinary Clinics: Food Animal Practice, v.30, n.3, p.643-670, 2014. Available from: < https://www.vetfood.theclinics.com/article/ S0749-0720(14)00057-7/abstract>. Accessed Jul. 22, 2018. doi:10.1016/j.cvfa.2014.07.007.

RADOSTITS, O.M. et al. Veterinary Medicine: a textbook of the diseases of cattle, sheep, goats, pigs and horses. 10.ed. Saunders: Elsevier, 2007, pp. 2065.

RIBEIRO FILHO, J.D.; et al. Enteral fluid therapy in cattle: evaluation of isotonic electrolyte solutions administered via nasogastric tube on continuous flow. Ciência Rural, v.41, n. 2, p. 285-290, 2011. Available from: <https:/www.redalyc.org/ html/331/33117740031/>. Accessed Jul. 22, 2018. doi:10.1590/ S0103-84782011005000012.

ROUSSEL, A.J. Fluid therapy in mature cattle. Veterinary Clinics: Food Animal Practice, v.30, n.2, p.429-439, 2014. Available from: <https://www. vetfood.theclinics.com/article/S0749-0720(14)00032-2/ abstract $>$. Accessed Jul. 22, 2018.doi:10.1016/S07490720(15)30163-8.

SMITH, B.P. Large animal internal medicine, 5th ed., St Louis: Elsevier Saunders, 2015, pp. 2024. 